\title{
Snow impact on groundwater recharge in Table Mountain Group aquifer systems with a case study of the Kommissiekraal River catchment South Africa
}

\author{
Yong $\mathrm{Wu}^{*}$ and Yongxin $\mathrm{Xu}$ \\ Department of Earth Sciences, University of the Western Cape, Private Bag X17, Bellville 7535, South Africa
}

\begin{abstract}
Snowmelt in the mountainous areas of the Table Mountain Group (TMG) in South Africa is believed to be one of sources of groundwater recharge in some winter seasons. This paper provides a scientific assessment of snow impact on groundwater recharge in Table Mountain Group Aquifer Systems for the first time. Snowfall periodically occurs on the highest mountain ranges of about 1000 to $1200 \mathrm{~m}$ above mean sea level (a.m.s.l) in the TMG area. Snow over the mountainous catchments is often observed on the gentle side of the slope, which is substantially affected by wind and vegetation. Based on climatic analysis, recharge processes and Landsat 7 Enhanced Thematic Mapper (ETM) images, the recharge areas influenced by snowmelt in the TMG are identified as those catchments that are located above $1000 \mathrm{~m}$ a.m.s.l. Physical processes within the snowpack are very complex involving mass and energy balances as well as heat and mass transport. Snowmelt rate was calculated using a variable degree-day melt factor determined as a function of snowpack density and vegetation cover. The hourly snowmelt rates estimated with different new snow density models. Groundwater recharge from snowmelt is affected by snowmelt mechanisms and local recharge conditions. The recharge rate is constrained by characteristics of the fractures rather than snowmelt rate. Recharge is also discounted due to prevailing interflow occurring in favourite geomorphological locations. This hypothesis is confirmed by an infiltration experiment in which up to $13.6 \%$ of the infiltrating water can recharge the aquifer. The estimated snowmelt recharge in the Kommissiekraal River catchment in the Villiersdorp of South Africa ranges from $14.1 \ell \cdot \mathrm{s}^{-1}$ to $15.0 \ell \cdot \mathrm{s}^{-1}$.
\end{abstract}

Keywords: recharge, snowmelt, TMG, Kommissiekraal River catchment, ETM image

\section{Introduction}

Snow cover is an important hydrological phenomenon. Snowmelt is one of the sources of water in the TMG mountainous area. It may significantly contribute to runoff and produce considerable recharge as well. At the same time, seasonal snow cover would affect biotic components and water quality in river basins. Distributed modelling of snow accumulation and melt is therefore an important issue. Three groups of the snowmelt models, namely index models, energy-based models and detailed models, have been developed to describe the snow-water equivalent (Parajka et al., 2004).

In recent years, distributed snowmelt models have become increasingly commonplace in hydrological research (Blöschl et al., 1991a, b; Cazorzi and Dalla Fontana, 1996; Cline et al., 1998; Luce et al., 1998 and 1999; Dunn and Colohan, 1999; Hartman et al., 1999; Marks et al., 1999). Their growth in popularity has been driven by increased computing power and availability of digital elevation and remote-sensing data, and an increased appreciation of the importance of spatial variability and scale in the adequate prediction of catchment runoff response (Kirnbauer et al., 1994; Blöschl, 1999; Anderton et al., 2003). However, models of this type require a large amount of diverse spatial and temporal data for parameter estimation, specification of initial conditions, model forcing, calibration and validation (Anderton

\footnotetext{
* To whom all correspondence should be addressed.

证 +2721 959-2413; fax: +2721 959-3118;

e-mail: ywu@uwc.ac.za

Received 19 November 2004; accepted in revised form 2 May 2005
}

et al., 2003). This is especially problematic for mountainous areas, where rugged topography tends to promote great heterogeneity in meteorological conditions and in the distribution of the snow-water equivalent. Remote sensing has become increasingly important in mapping the snow-cover extent in mountainous areas (Rango, 1993). However, no method exists yet for evaluation of catchment snow-water equivalent, using remote sensing at the spatial scales required to characterise the spatial variability typically found in mountainous areas (Cline et al., 1998). The distribution of the snow-water equivalent and meteorological inputs therefore must be interpolated from terrestrial measurements (Anderton et al., 2003).

Topography exerts a strong control on the physical processes controlling snow accumulation and melt. Quantifying relationships between snow distribution and the terrain characteristics of mountain catchments is an area of research that has attracted considerable interest recently (Anderton et al., 2003). A number of studies have used regression-type approaches to model the distribution of the snow-water equivalent of the probability of snow cover as a function of topographic indices (Hosang and Dettwiler, 1991; Blöschl and Kirnbauer, 1992; Cline, 1992). Multivariate statistical analysis was used to explore relationships between catchment topography and spatial variability in snow accumulation and melt processes in a small headwater catchment in the Spanish Pyrenees (Anderton et al., 2003).

Snow cover can significantly influence energy and moisture fluxes between the earth's surface and the atmosphere. Snowcovered surfaces absorb much less solar radiation than most other natural surfaces (Strack et al., 2004). In addition, snowcovered surfaces are limited to a maximum temperature of $0^{\circ} \mathrm{C}$. Finally, because of its low thermal conductivity, snow acts as 


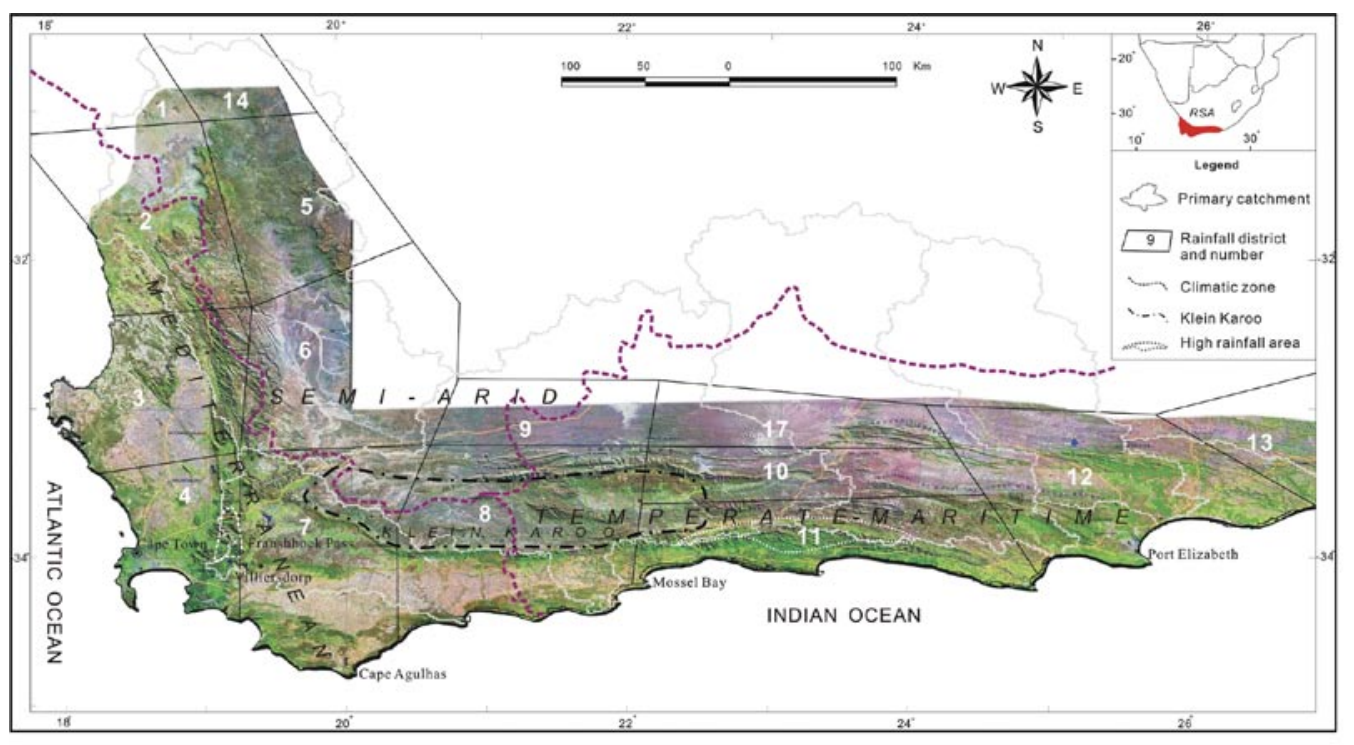

Figure 1 Homogeneous rainfall districts in the TMG area

an insulating blanket that decouples the soil and atmosphere. A number of studies (Namias, 1985; Cohen and Rind, 1991; Baker et al., 1992; Leathers and Robinson, 1993; Ellis and Leathers, 1998; Taylor et al., 1998; Strack et al., 2003) have shown that the presence of snow can significantly reduce air temperatures through the processes of energy and moisture fluxes. When tall vegetation such as shrubs or trees protrude through the snowpack, they absorb more solar radiation and warmth relative to surrounding snow, thus providing a boundary layer heat source (Strack et al., 2004).

There has been no study about snowmelt impact on groundwater recharge in South Africa until now. The work presented in this paper seeks to explore relationships between mountain characteristics and snow distribution and snowmelt processes in the TMG area. Furthermore, the study attempts to discuss topographic controls not only on snow accumulation, but also on melt, and, therefore, on the timing of snowpack disappearance over the course of the melt season. Finally, the impact of snowmelt on recharge will be discussed. The objective of the work is to provide greater insight into the influence of snow and snowmelt in high mountainous areas. It is hoped that the results presented herein will ultimately contribute to improved methods for the recharge estimation in mountain catchments of the TMG

\section{Physiography}

The Table Mountain Group forms rugged mountainous areas with altitudes ranging from $200 \mathrm{~m}$ to $2250 \mathrm{~m}$. To the northeast of the mountains lies the relatively high altitude plateau of the Karoo at an elevation of between $800 \mathrm{~m}$ and $2000 \mathrm{~m}$. The NW-SE trend of the mountains in the west section runs parallel to the coastline and consists of the Bokkeveld, Piketberg, Cedarberg, Skurweberg, Cold Bokkeveld and Witzenberg Mountains. The western section includes the Koue Bokkeveld range and the Cederberg mountain ranges along the internal divide between the upper Olifants River and Doring drainage basins. It also incorporates the Winterhoek and Witzenberg ranges around the triple junction between the $\mathrm{E}, \mathrm{G}$, and $\mathrm{H}$ primary drainage regions. Inter-mountain valleys are generally formed by synclinal structures in the TMG strata. In the central area, the mountain ranges strike northeast, such as the Hex River Moun- tains, Riviersonderend and Overberg Mountains. The drainage systems are the Breede River and Groot (Gouritz) River in the central area. The Swartberg Mountains lie in the north, and the Langeberg Range and Outeniqua Mountains in the southern EW striking range, which runs parallel to the coastline with the Kammanassie Mountain range, lying in the east between them. The topography of the eastern section is largely characterised by a number of NW-SE striking mountain ranges and ridges, such as the Kouga, Tsitsikamma-Kareedouw, Baviaanskloof, Grootrivier Mountain and Great Winterhoek Mountains. The Olifants River (Oudtshoorn area), Keurbooms and Gamtoos Rivers are the main drainage systems in the eastern section of the TMG.

Figure 1 depicts the standard 15 homogeneous rainfall districts over the TMG area as defined by the South African Weather Service (SAWS). The mean annual precipitation [MAP] varies between $>1000 \mathrm{~mm}$ in most mountainous areas higher than $1500 \mathrm{~m}$ and $<300 \mathrm{~mm}$ in the low elevation and Karoo areas (Midgley et al., 1994). Precipitation is clearly orographically influenced in the TMG area. The two white dash circles in Fig. 1 indicate high rainfall areas with higher than $1500 \mathrm{~mm} / \mathrm{a}$ in the mountainous areas close to Franschhoek and Humansdorp.

The western area lies within the winter rainfall region and has a Mediterranean climate with a marked seasonality of precipitation. Winter precipitation is mainly from a westerly direction due to cold fronts crossing the South Atlantic and Southern Oceans. MAP varies widely between $>1000 \mathrm{~mm}$ and $<200 \mathrm{~mm}$, being lowest along the coastal plain where the aridifying effects of the cold Benguella upwelling system are felt (Midgley et al., 1994). The localised effects of the annually variable winter snowfall on the highest peaks, e.g. Sneeuberg $(2037 \mathrm{~m})$ in the Cederberg Range, and Sneeugat (1 $884 \mathrm{~m})$ in the Winterhoek Range, may also require a more specialised hydrological study.

The syntaxis areas fall largely within the winter rainfall region. Winter snowfalls periodically occur on the highest mountain ranges. Annual rainfall varies between 300 and $500 \mathrm{~mm}$ along the west and south coasts, between 200 and $300 \mathrm{~mm}$ in the Breede River Valley, between 100 and $200 \mathrm{~mm}$ in the Karoo and are above $1000 \mathrm{~mm}$ in the mountainous regions (Meyer, 2001).

The Klein-Karoo and Karoo regions have typical semi-desert climates, hot summers and mild winters with summer temperatures regularly exceeding $30^{\circ} \mathrm{C}$. Precipitation occurs year-round with average precipitation on the coastal plain varying between 
Figure 2

ETM images of

snow (blue) on

mountain peaks in the TMG

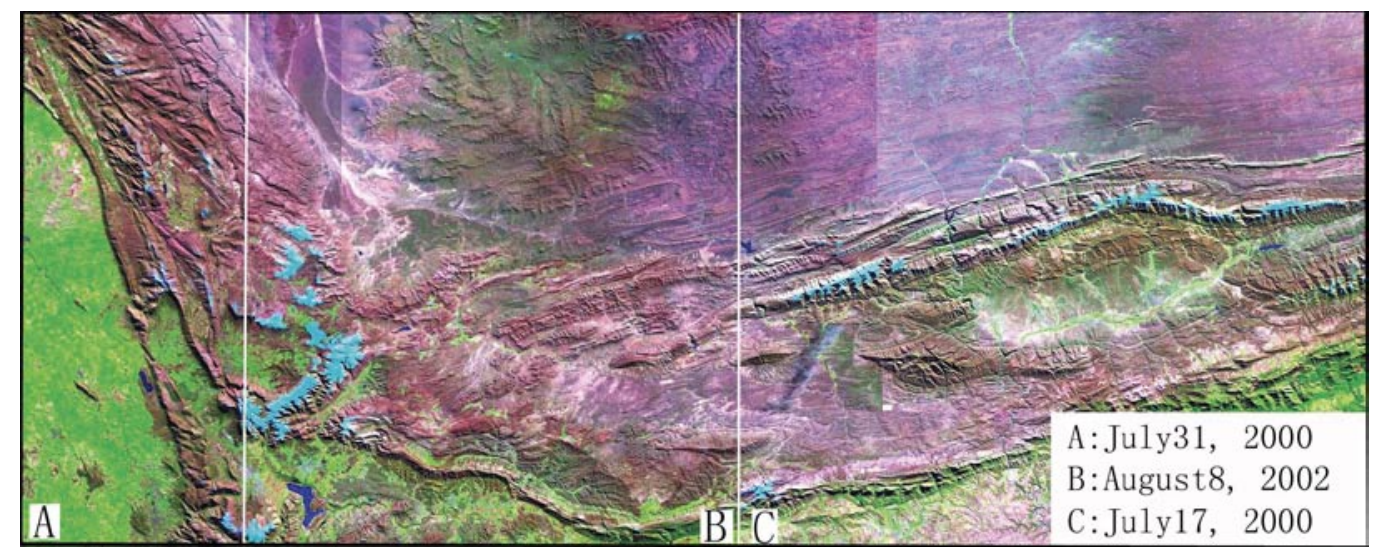

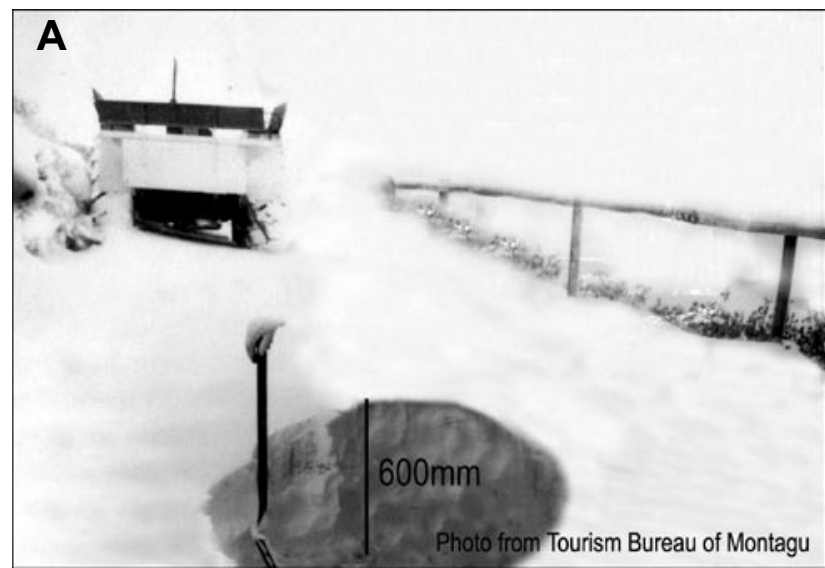

$432 \mathrm{~mm}$ at Riversdale and $867 \mathrm{~mm}$ at George. Precipitation diminishes rapidly northwards with average annual precipitation at Oudtshoorn in the Little Karoo and Prince Albert in the Karoo being 245 and $174 \mathrm{~mm}$ respectively (Meyer, 1999).

The TMG sandstone is a regional fractured-rock aquifer with the potential to be the major source of future bulk water supplies to meet both agricultural and urban requirements in the Western and Eastern Cape Provinces in South Africa. The TMG aquifer comprises an approximately $4000 \mathrm{~m}$ thick sequence of sandstone, shale and quartz arenite that is exploited extensively for agricultural purposes. The TMG comprises the Piekenierskloof Formation, Graafwater Formation, Peninsula Formation, Pakhuis Formation, Cederberg Formation and Nardouw Subgroup. Mountain Fynbos shrub is the main vegetation type growing in the TMG mountainous area.

\section{Spatial distribution of snow}

The distribution of snow is associated with topography, season and temperature in the TMG area. Winters in the mountainous areas are cold and wet, night temperatures drop sharply and heavy frost and snow may occur. The distribution of snow occurs above 1000 to $1200 \mathrm{~m}$ a.m.s.l. of the TMG mountainous area in some winter seasons. The distribution of snow in the TMG area is shown on the Landsat 7 Enhanced Thematic Mapper (ETM) images as seen in Fig. 2. Different distributions occurred in different seasons or periods, and snow cover remained on the gentle slope sides, e.g. the northwest slope of the Hex River Mountain and the northern slope of the Swartberg Mountain. This was also related to wind field and direction. As seen in Fig. 2A snow remains slightly longer on the mountain peaks

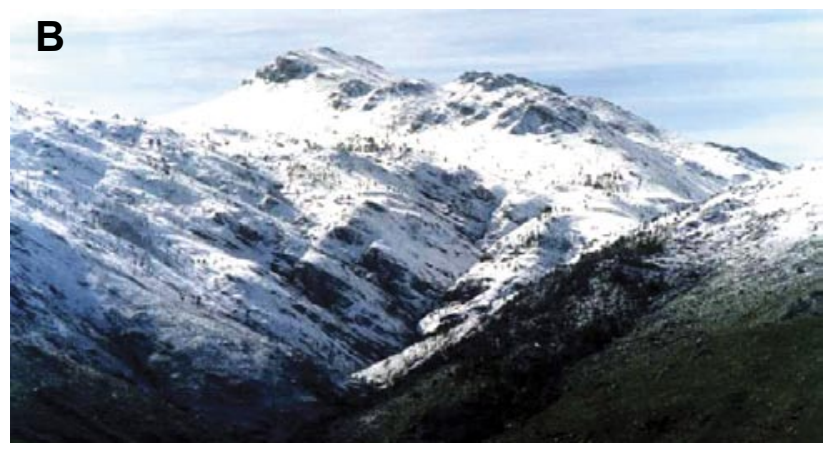

Figure 3

Snow on the Langeberg Mountain near the Protea Farm (left) and peaks above the Franschhoek Pass (right) in 2000

due to snow thickness. On 8 August 2002, a wide distribution of snow occurred from the Gydoberg in the north, the Hex River Mountain in the middle to the Du Toitsberg Mountains in the south as can be seen in Fig. 2B. A small area of snow cover distributes on the peaks of the Kammanassie Mountain and Marloth as shown in Fig. 2C.

The thickness of snow was up to $600 \mathrm{~mm}$ in the Langeberg Mountain at the Protea Farm and peaks above Franschhoek Pass in the year 2000 as can be seen in Fig. 3 . Less snow occurred on the side sheltered from the wind. The interflow from snowmelt was observed. This means that the percolation rate was smaller than the snowmelt rate. Based on ETM images and climatic analysis, the snow-influenced recharge areas in the TMG area are shown in Fig. 4. The influenced areas are much wider than the snow cover area. Snow is distributed widely on the mountainous peaks and places of high elevation, but snowmelt can influence the entire catchments or outcrops of the TMG. Therefore, recharge from snowmelt must be considered in these mountainous catchments.

\section{Impact of snowmelt on recharge}

Physical processes within the snowpack involve mass and energy balances as well as heat and mass transport. Snowmelt is an energy-driven process. Recharge processes are associated with fractures, soils and vegetation, especially characteristics of fractured rocks at depth. Groundwater recharge from snowmelt is related not only to snowmelt mechanisms and processes but also to recharge processes. Snow-water equivalent can be used to characterise the snowpack and snowmelt rate. Introduction of the snow-water equivalent to the TMG recharge calculation has 


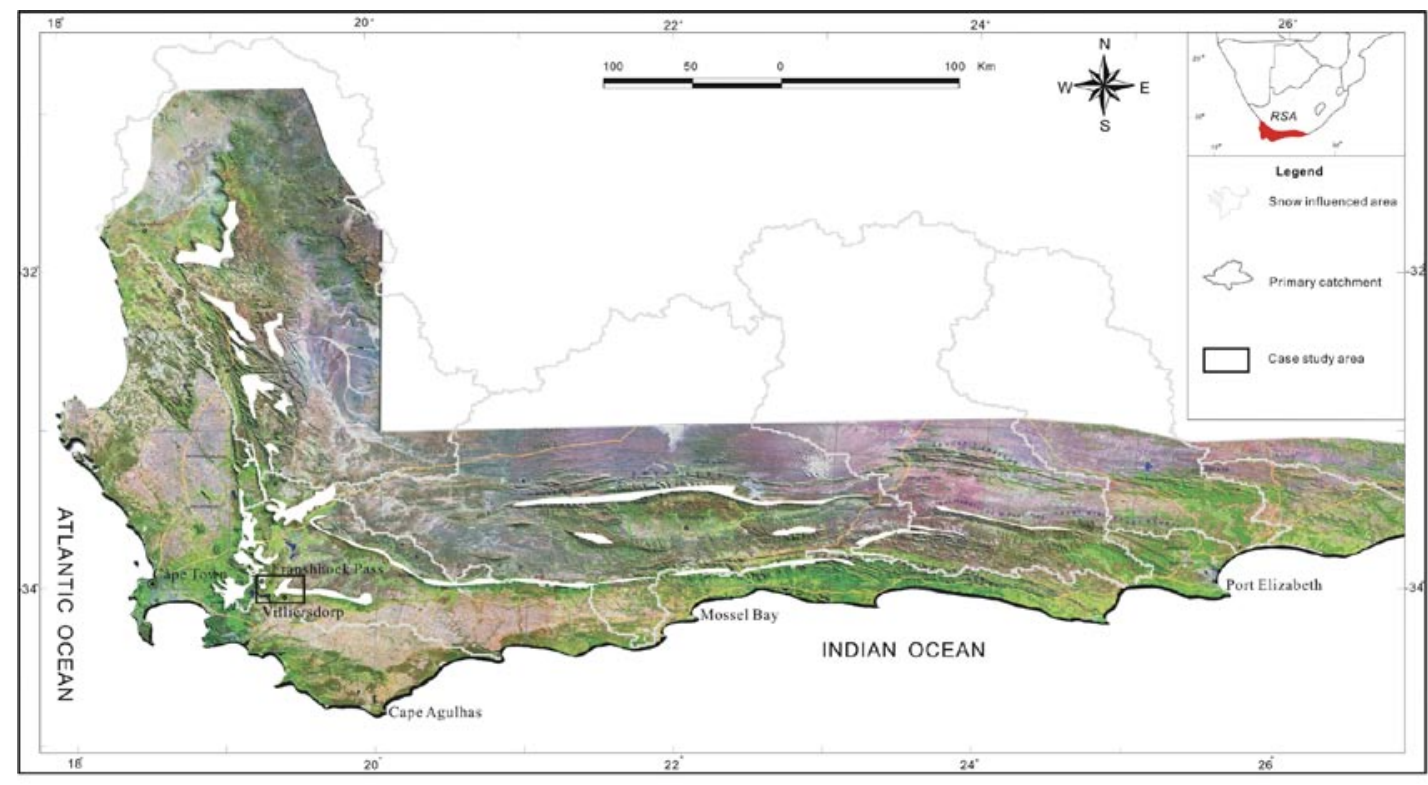

Figure 4

Snow-influenced area in the TMG area (white)

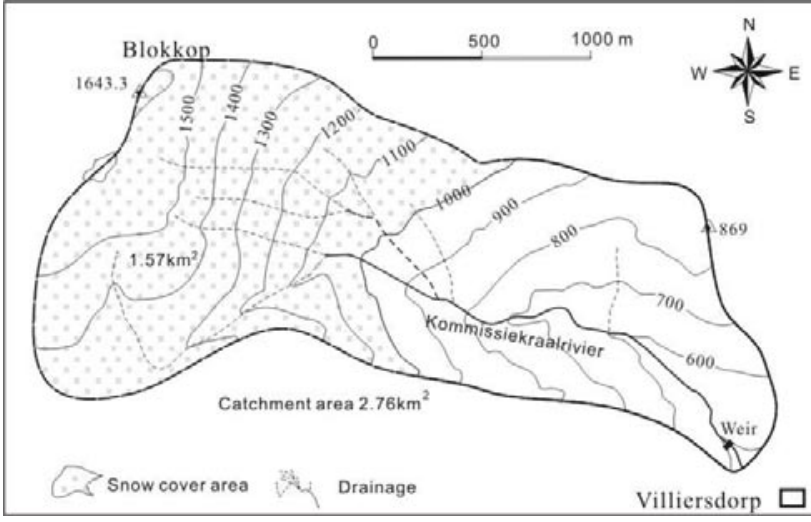

Figure 5

Elevation map of study area, showing the snow cover area in August 2003

a significant impact on sustainable development of groundwater recourses in the TMG region. The recharge estimates calculated without considering the snow-water equivalent would be inaccurate. As the snowmelt occurs simultaneously over a wide range of TMG area, its impact on recharge has a regional effect rather than the local one. Baseflow separation from hydrographs needs to take into account the snowmelt in the catchments affected by snow. The relationship established between rainfall and the groundwater level in boreholes needs to be reviewed in order to incorporate the snowmelt event into the water level fluctuation analysis. A case study and an infiltration experiment are used to illustrate calculation of the recharge from the snow-water equivalent.

\section{Case study}

The case study was conducted in the Villiersdorp Wild Flower Garden and Nature Reserve (VWFGNR) in the Villiersdorp, Western Cape South Africa, located at $19^{\circ} 17^{\prime}$ E and $33^{\circ} 58^{\prime} \mathrm{S}$ (Fig. 5). The VWFGNR area is a typical physiographical feature of the cuesta, characterised by a cold winter climate and small platform in the mountain ridge. The Wild Flower Garden and Nature Reserve border the edge of the town on the slopes of Aas- voël Mountain and Blokkop Peak with $1643.3 \mathrm{~m}$ a.m.s.l in the northwest of the study area. The nature reserve on the outskirts of town gives a wonderful display of 60 Protea species including the giant King Protea with blooms almost $0.5 \mathrm{~m}$ across (CNC Website). A small dam with $6.7 \mathrm{~m}$ lengths across the section of the Kommissiekraal River is located at the elevation of 500 $\mathrm{m}$ a.m.s.l. A trapezoidal weir was constructed in the middle of the dam with a bottom width of $801 \mathrm{~mm}$ and top width of 1001 $\mathrm{mm}$ and depth of $440 \mathrm{~mm}$. A delivery pipe with an inner diameter of $140 \mathrm{~mm}$ is located at the bottom of the dam with a water head of $1.4 \mathrm{~m}$ upwards of the water surface.

The temperature during the hot summer months (October to February) can be in excess of $40^{\circ} \mathrm{C}$, while during the cold winter months (June to August), temperatures are sometimes below $0^{\circ} \mathrm{C}$ on the north side of the mountain during the night. Monthly average maximum temperatures vary from $40^{\circ} \mathrm{C}$ in January to $19^{\circ} \mathrm{C}$ in July in the mountain areas, whereas the monthly average minimum temperatures range from $7.5^{\circ} \mathrm{C}$ in January to $-4^{\circ} \mathrm{C}$ in July.

The study area belongs to the winter rainfall district. Most rainfall falls during August, September, October and November as can be seen in Fig. 6. The annual mean rainfall is $608 \mathrm{~mm}$ (1924 to 1981) and in winter the surrounding mountain peaks are often snow-capped. Approximately $300 \mathrm{~mm}$ of snow occurred on the Villiersdorp Mountain in August 2003 as can be seen in Fig. 7. The more the grass cover, the less the snow cover present, and the less the grass cover, the faster the snowmelt occurred. Less snow occurred on the side sheltered from the wind. The interflow from snowmelt was observed, which means that the percolation rate was lower than the snowmelt rate.

\section{Snowmelt calculation}

The snowpack on a snow-band may melt both at the snow-air interface and the snow-ground interface (US Army Corps of Engineers, 1991). A different calculation of snowmelt at the snowair interface is made depending upon the absence or presence of rain. The clear weather melt is calculated by the temperature index approach as follows (Anderson, 1973):

$$
\mathrm{M}=\operatorname{MF}\left(\mathrm{T}_{\mathrm{a}}-\mathrm{T}_{\mathrm{b}}\right)
$$




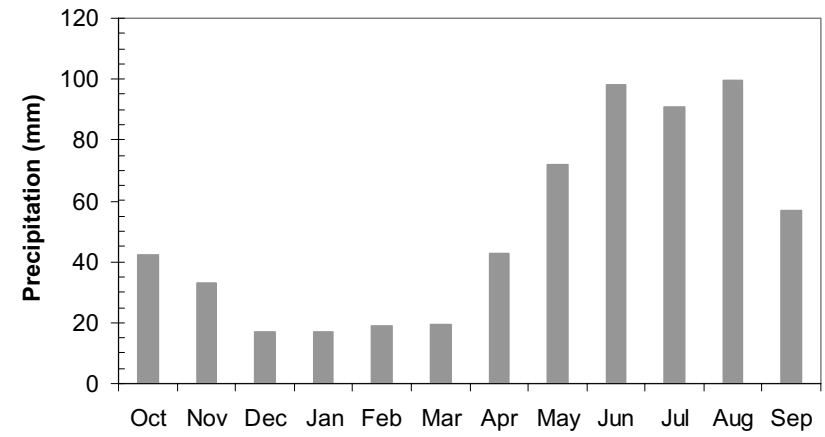

Figure 6

Monthly average precipitation of rainfall station with code 0022539 in the Villiersdorp. The results are statistical values from 1924 to 1981.

where:

$\mathrm{M}$ is the daily snowmelt depth (mm),

$\mathrm{MF}$ is the melt factor, rate of melt per degree per unit time $\left(\mathrm{mm} \cdot{ }^{\circ} \mathrm{C}^{-1} \cdot \mathrm{h}^{-1}\right)$, range from 0.1 to $0.5 \mathrm{~mm} \cdot{ }^{\circ} \mathrm{C}^{-1} \cdot \mathrm{h}^{-1}$.

Donald (1992) found that values of $0.20 \mathrm{~mm} \cdot{ }^{\circ} \mathrm{C}^{-1} \cdot \mathrm{h}^{-1}$ produced reasonable results. $\mathrm{T}_{\mathrm{a}}$ is the air temperature $\left({ }^{\circ} \mathrm{C}\right)$, and $\mathrm{T}_{\mathrm{b}}$ is the temperature at which the snow begins to melt $\left({ }^{\circ} \mathrm{C}\right)$. Based on Anderson (1973) with an MF of $0.20 \mathrm{~mm} \cdot{ }^{\circ} \mathrm{C}^{-1} \cdot \mathrm{h}^{-1}$, the snowmelt fluxes at 4 and $6^{\circ} \mathrm{C}$ are 1.04 and $1.44 \mathrm{~mm} \cdot \mathrm{h}^{-1}$, respectively.

In comparison to the results from the Anderson (1976) model, another model for hourly melt of snow using a standard temperature index approach is as follows (Ross et al., 2003):

$$
\omega=\frac{\gamma}{24}\left(T_{\text {air }}-T_{\text {melt }}\right)
$$

where

$\omega$ is the hourly melt rate

$\mathrm{T}_{\text {melt }}$ is the threshold air temperature for snowmelt

$\gamma$ is variable degree-day melt factor.

A variable degree-day melt factor $(\gamma)$ determined as a function of snowpack density $(\rho)$ and vegetation cover (open/forested) (Kuusisto, 1984):

$$
\begin{aligned}
& \gamma=0.0104 \rho_{s}-0.70, \\
& \left(1.4<\gamma<3.5 \text { in forested areas }\left(\mathrm{mm} \cdot \mathrm{d}^{-1}\right)\right. \\
& \gamma=0.0196 \rho_{s}-2.39 \\
& \left(1.5<\gamma<5.5 \text { in open areas }\left(\mathrm{mm} \cdot \mathrm{d}^{-1}\right)\right.
\end{aligned}
$$

New snowfall density $\rho_{\text {sfall }}$ was assumed to be a function of air temperature $\left(\mathrm{T}_{\mathrm{air}}\right)$, and was calculated as follows (Hedstrom and Pomeroy, 1998):

$$
\begin{array}{ll}
\rho_{\text {sfall }}=67.9+51.3 \exp \left(T_{\text {air }} / 2.6\right) & \mathrm{T}_{\text {air }} \leq 0^{\circ} \mathrm{C} \\
\rho_{\text {sfall }}=119.2+20.0 T_{\text {air }} & \mathrm{T}_{\text {air }} \geq 0^{\circ} \mathrm{C}
\end{array}
$$

A comparison density of new snow is calculated from (Anderson, 1976):

$$
\rho_{\mathrm{s}}=50+1.7\left(\mathrm{~T}_{\mathrm{wb}}-258.16\right)^{1.5}
$$

where:

$\rho_{\mathrm{s}}$ is the snow density in kilograms per $\mathrm{m}^{3}$

$T_{\mathrm{wb}}$ is the wet-bulb temperature of the near surface air in Kelvin
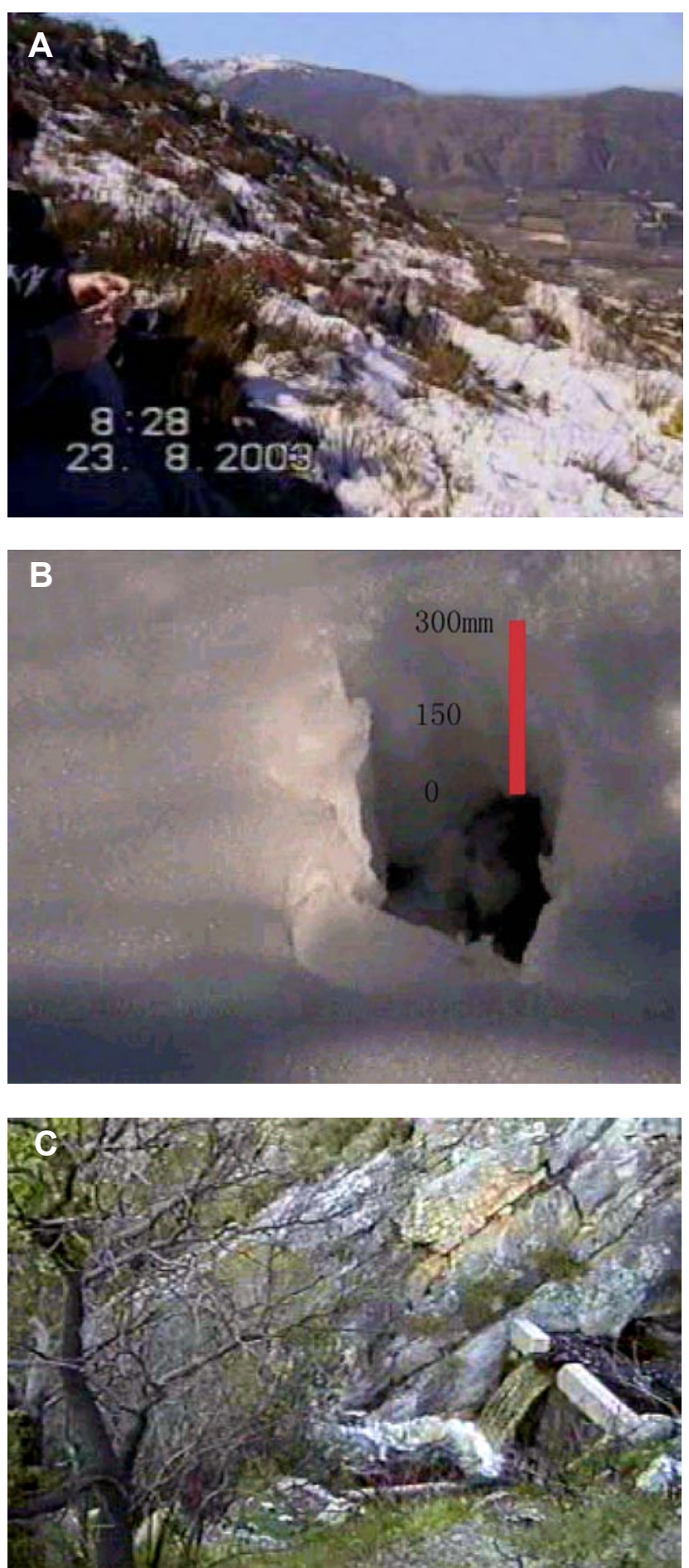

Figure 7

Snow and interflow from snowmelt in the Villiersdorp Mountain in August 2003

This equation is used to calculate precipitation density if the air temperature is less than or equal to $0^{\circ} \mathrm{C}$.

There is considerable variability in published values of $\mathrm{T}_{\text {melt }}$ and a value of less than $0^{\circ} \mathrm{C}$ is not physically unrealistic since radiation melt can take place when air temperatures are below freezing (Ross et al., 2003). Kuusisto (1984) obtained $\mathrm{T}_{\text {melt }}$ values of $-1.3^{\circ} \mathrm{C}$ and $-1.2^{\circ} \mathrm{C}$ for open and forested sites in Finland. These values are used for calculating hourly melt rate in the TMG mountainous area. 


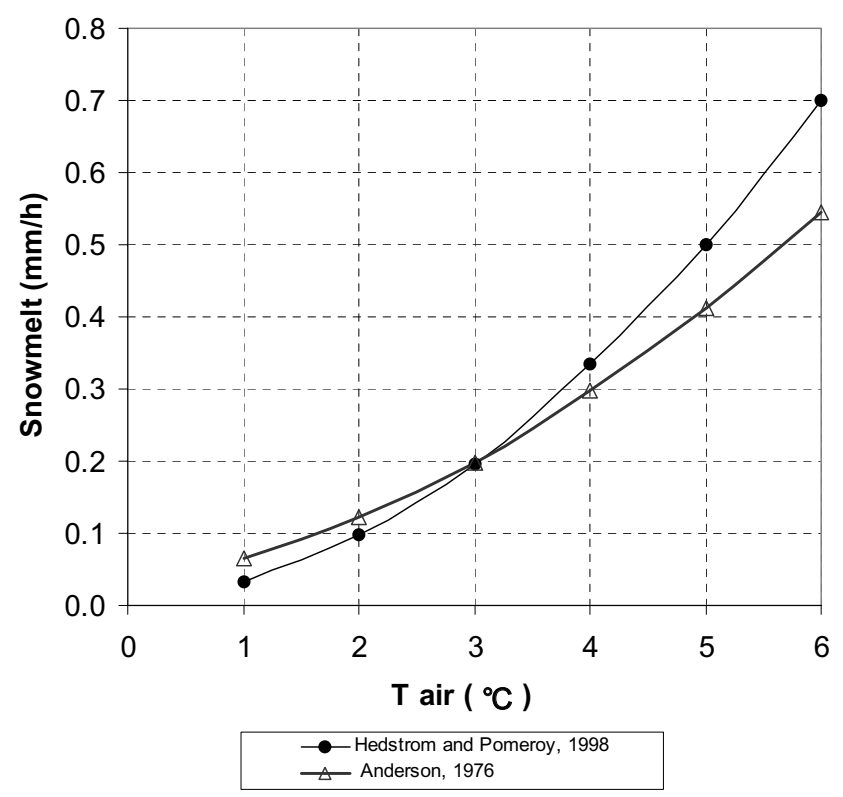

Figure 8

Hourly snowmelt rate based on different newly fallen snow density model for open sites

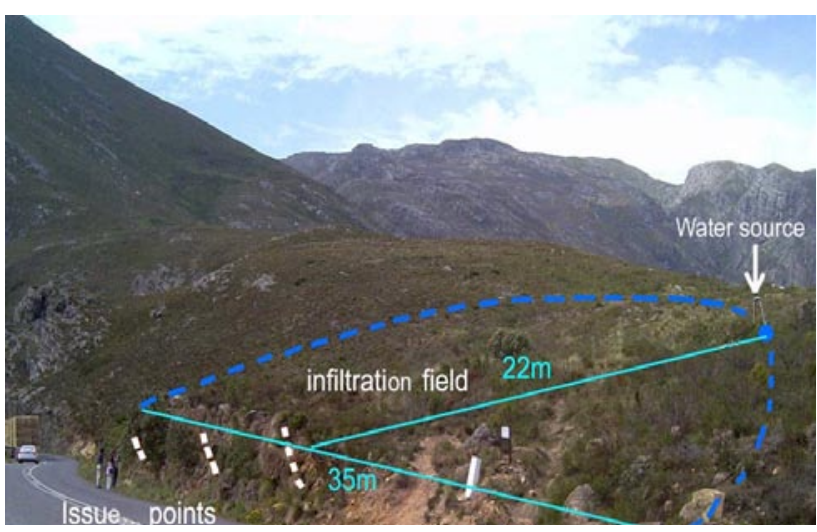

Figure 9

Infiltration experiment

The hourly snowmelt rate in the study area based on the Anderson (1976) new snow density model is less than that based on the Hedstrom and Pomeroy (1998) new snow density if air temperature is below $3^{\circ} \mathrm{C}$, but a reverse occurs if the air temperature is above $3^{\circ} \mathrm{C}$ as shown in Fig. 8 .

\section{Formation of interflow by snowmelt}

As Fig. 7 shows, the snowmelt water infiltrates to the soils and fractured rocks and emerges as interflow. Many chemical materials were dissolved resulting in the brown colour appearing in the interflow. The flow at the weir was measured at $160 \mathrm{~mm}$ depth. The flux of the weir was calculated with Bazin weir formula (Darcy and Bazin, 1865):

$$
Q=0.42 b \sqrt{2 g} h^{\frac{3}{2}}
$$

where:

$\mathrm{b}$ is the width of the weir,

$\mathrm{h}$ is the height of water above floor,

$\mathrm{g}$ is the standard acceleration of gravity in $\mathrm{m} \cdot \mathrm{s}^{-2}$

\begin{tabular}{|c|c|c|}
\hline \multicolumn{3}{|c|}{\begin{tabular}{|c|} 
TABLE 1 \\
Snowmelt flux in the Kommissiekraal River \\
catchment
\end{tabular}} \\
\hline \multirow{2}{*}{$\begin{array}{c}\text { Temperature } \\
\left({ }^{\circ} \mathrm{C}\right)\end{array}$} & \multicolumn{2}{|c|}{ Snowmelt flux $\left(\ell \cdot s^{-1}\right)$} \\
\hline & $\begin{array}{c}\text { Hedstrom and } \\
\text { Pomeroy Model, } \\
1998\end{array}$ & $\begin{array}{c}\text { Anderson } \\
\text { model, } 1976\end{array}$ \\
\hline 1 & 14.14 & 28.80 \\
\hline 2 & 42.47 & 53.70 \\
\hline 3 & 85.65 & 86.43 \\
\hline 4 & 145.84 & 129.76 \\
\hline 5 & 218.23 & 179.50 \\
\hline 6 & 304.87 & 238.01 \\
\hline Mean & 135.20 & 119.37 \\
\hline
\end{tabular}

The flux is calculated at $95.2 \ell \cdot \mathrm{s}^{-1}$, which equals $3.45 \times 10^{-8} \mathrm{~m} \cdot \mathrm{s}^{-1}$ related to the snow cover area of $1.57 \mathrm{~km}^{2}$ in the Kommissiekraal River catchment. The baseflow is approximately $1.5 \ell \cdot \mathrm{s}^{-1}$ at the weir based on the measured flux on 22 March 2005.

Supposing the total discharge at the weir in the snow season consists of groundwater discharge and snowmelt water, the recharge of snowmelt can be calculated if the groundwater discharge can be represented by the measurements taken at the weir during the dry season. In comparison with the calculated snowmelt flux in the Kommissiekraal River catchment (Table 1), the average snowmelt rate must be higher than the flux of interflow due to the fact that part of the snowmelt water can recharge the TMG aquifer. Based on Eq. (2), the calculated hourly melt rates would be higher than the interflow; which means the air temperatures are above $3.2^{\circ} \mathrm{C}$. The hourly melt rates calculated at air temperatures of 4 and $6^{\circ} \mathrm{C}$ are 129.76 to $145.84 \ell \cdot \mathrm{s}^{-1}$ and 238.01 to $304.87 \ell \cdot \mathrm{s}^{-1}$, respectively, in which approximately 26.6 to $68.8 \%$ of the snowmelt water percolates to the aquifer. It equals $8.27 \times 10^{-5}$ to $1.94 \times 10^{-4} \mathrm{~m} \cdot \mathrm{s}^{-1}$. These values are obviously overestimated.

\section{Comparison with infiltration experiment}

An infiltration experiment was performed at the Franschhoek Mountain Pass. As can be seen in Fig. 9 the source water was overflow of $1.107 \ell \cdot \mathrm{s}^{-1}$ from a pipe. The infiltration area was about $50 \mathrm{~m}^{2}$, and the specific infiltrating rate is $0.022 \ell \cdot \mathrm{s}^{-1} \cdot \mathrm{m}^{-2}$. The discharge sector is about $385 \mathrm{~m}^{2}$. The issuing zones are the bedding fractures on the side of the steep slope. A few of more seepage zones were also observed at lower elevation but with less magnitude. A small temporal weir was used to collect the discharge water in the main discharge zones. The discharge rate was measured at 0.956 to $0.964 \ell \cdot \mathrm{s}^{-1}$, which was not total discharge water. The recharge percentage was estimated at 12.9 to $13.6 \%$. Therefore, most infiltrating water seeps out as interflow.

Assuming that the geological conditions of the snowpack in the Kommissiekraal River catchment are similar to the Franschhoek Mountain Pass, the snowmelt recharge in the TMG aquifer is estimated to be between $14.1 \ell \cdot \mathrm{s}^{-1}$ and $15.0 \ell \cdot \mathrm{s}^{-1}$, which equals $8.98 \times 10^{-6} \mathrm{~m} \cdot \mathrm{s}^{-1} \cdot \mathrm{m}^{-2}$ to $9.54 \times 10^{-6} \mathrm{~m} \cdot \mathrm{s}^{-1} \cdot \mathrm{m}^{-2}$ in the Kommissiekraal River catchment.

\section{Discussion}

Due to the short duration of snowmelt and the lack of temperature data of the air and soil in those periods, errors would occur in the snowmelt calculation. The accuracy of the calculation 
would be obtained with the observed parameters such as air temperature, water vapour mixing ratio, wind speed, precipitation, soil temperature and moisture, solar radiation and downward atmospheric long-wave radiation. The observed snow depths and stay time, the peak water level and the fluctuation of the flux recession at the weir should be monitored within the snow season in order to gain some highly accurate results of how much these recharges would be produced.

An overall goal of this study was to determine the recharge by means of the snowmelt calculation. An accurate estimate of the flux of the weir is necessary to determine the rate of infiltration to the subsurface when the vegetation is masked by the snow. The uncertainty of the snowmelt rate suggests that the calculation would give the poorest estimates of the recharge in the catchment where the snow cover is a relatively small percentage of the entire catchment. In the case of snowpack, which is distributed over typically higher elevation mountainous areas, the difference of snow depth within the snowpack would have a large influence on the estimate of recharge. Precipitation in non-snowpack within the catchment during the same period as the snow event can produce an error as well.

A logical next step in our effort to accurately estimate surface fluxes in snow-shrub environments is to test the recharge estimates against observations. In addition, once the fluxes have been verified against observed values, the role of snowmelt in the TMG mountainous will be very useful in recharge estimation against precipitation (snow) event.

In the TMG mountainous areas, the melt time is estimated as $6 \mathrm{~d}$ if the average snow thickness is $100 \mathrm{~mm}$, which equals to rainfall of $21.9 \mathrm{~mm}$. Considering infiltrating conditions, more runoff should occur if the snowmelt time is shorter than time of the equivalent rainfall, because recharge is constrained by fracture properties while snowmelt rate is not. Notice that recharge from snowmelt is a complicated process, which is related to snowmelt mechanisms and infiltrating processes. Infiltration or recharge cannot occur in solid ground surfaces but only in open fractures.

\section{Conclusion}

According to the distribution of snow, the recharge areas influenced by snowmelt in the TMG are the catchments above $1000 \mathrm{~m}$ a.m.s.l. The hourly snowmelt rates estimated with different new snow density models. These snowmelt rates are the ceiling of the percolation. The recharge rate is constrained by fracture characteristics rather than by the snowmelt rate itself, as most of snowmelt water emerges in the form of interflow. Recharge rates must be much lower than snowmelt rates. The infiltration experiment confirms that less than $13.6 \%$ of infiltrating water can recharge the TMG aquifer. The snowmelt recharge of the TMG aquifer is estimated at between $14.1 \ell \cdot \mathrm{s}^{-1}$ to $15.0 \ell \cdot \mathrm{s}^{-1}$ in the Kommissiekraal River catchment. As the snowmelt occurs in a wide range of TMG areas, its impact on recharge has a regional effect rather than a local one, especially on baseflow separation from hydrographs. Further research is needed to compare snowmelt recharge with that of normal rainfall conditions.

\section{Acknowledgements}

The Water Research Commission (WRC) in Pretoria is thanked for financial support of this research. The authors are grateful to the VLIR UWC Water Project for additional support during field investigations. The authors would like to thank Yang Liu of the University of Stellenbosch for providing some snow photographs.

\section{References}

ANDERSON EA (1973) National Weather Service River Forecast System-Snow Accumulation and Ablation Model. National Oceanographic and Atmospheric Administration, Silver Springs, Md., Tech. Memo NWS HYDRO-17.

ANDERSON EA (1976) A Point Energy and Mass Balance Model of a Snow Cover. NOAA, Technical Report, NWS-HYDRO-19. $150 \mathrm{pp}$.

ANDERTON SP, WHITE SM and ALVERA B (2003) Evaluation of spatial variability in snow water equivalent for a high mountain catchment. Hydrol. Process. Published online in Wiley InterScience (www.interscience.wiley.com). DOI: 10.1002/hyp.1319.

BAKER DG, RUSCHY DL, SKAGGS RH AND WALL DB (1992) Air temperature and radiation depressions associated with a snow cover. J. Appl. Meteorol. 31 247-254.

BLÖSCHL G (1999) Scaling issues in snow hydrology. Hydrol. Process. 13 2149-2175.

BLÖSCHL G and KIRNBAUER R (1992) An analysis of snow cover patterns in a small alpine catchment. Hydrol. Process. 6 99-109.

BLÖSCHL G, GUTKNECHT D and KIRRNBAUER R (1991a) Distributed snowmelt simulations in an alpine catchment 2. Parameter study and model predictions. Water Resour. Res. 27 3181-3188.

BLÖSCHL G, KIRNBAUER R and GUTKNECHT D (1991b) Distributed snowmelt simulations in an alpine catchment 1 . Model evaluation on the basis of snow cover patterns. Water Resour. Res. 27 3171-3179.

BREIMAN L, FRIEDMAN J, OLSHEN R and STONE C (1984) Classification and Regression Trees. Chapman \& Hall/CRC, Boca Raton, FL.

CAZORZI F and DALLA FONTANA G (1996) Snowmelt modelling by combining air temperature and a distributed radiation index. J. Hydrol. 181 169-187.

CLINE DW (1992) Modeling the redistribution of snow in alpine areas using geographical information processing techniques. In: Ferrick M (ed.) Proc. 1992 Eastern Snow Conference, Oswego, New York. 13-24.

CLINE DW, BALES RC and DOZIER J (1998) Estimating the spatial distribution of snow in mountain basins using remote sensing and energy balance modeling. Water Resour. Res. 34 1275-1285.

COHEN J and RIND D (1991) The effect of snow cover on climate. J. Clim. 4 689-706.

DARCY H and BAZIN H (1865) Recherches Hydrauliques. Imprimerie Nationale, Paris.

DONALD JR (1992) Snowcover Depletion Curves and Satellite Snowcover Estimates for Snowmelt Runoff Modelling. Ph.D. Thesis, University of Waterloo, ON, Canada. $232 \mathrm{pp}$.

DUNN SM and COLOHAN RJE (1999) Developing the snow component of a distributed hydrological model: a step-wise approach based on multi-objective analysis. J. Hydrol. 223 1-16.

ELLIS AW and LEATHERS DJ (1998) A quantitative approach to evaluating the effects of snow cover on cold airmass temperatures across the U.S. Great Plains. Weather Forecast. 13 688-701.

HARTMAN MD, BARON JS and LAMMERS RB (1999) Simulations of snow distribution and hydrology in a mountain basin. Water Resour. Res. 35 1587-1603.

HEDSTROM NR and POMEROY JW (1998) Measurements and modelling of snow interception in the boreal forest. Hydrol. Process. 12 1611-1625.

HOSANG J and DETTWILER K (1991) Evaluation of a water equivalent of snow cover map in a small catchment area using a geostatistical approach. Hydrol. Process. 5 283-290.

HUTCHINSON MF (1989) A new procedure for gridding elevation and stream line data with automatic removal of spurious pits. J. Hydrol. 106 211-232.

KIRNBAUER R, BLÖSCHL G and GUTKNECHT D (1994) Entering the era of distributed snow models. Nordic Hydrol. 25 1-24.

KUUSISTO E (1984) Snow Accumulation and Snowmelt in Finland. 
Publications of the Water Research Institute, No. 55, National Board of Waters, Finland, Helsinki. 149 pp.

LEATHERS DJ and ROBINSON DA (1993) The association between extremes in North American snow cover extent and United States temperatures. J. Clim. 6 1345-1355.

LUCE CH, TARBOTON DG and COOLEY KR (1998) The influence of the spatial distribution of snow on basin-averaged snowmelt. Hydrol. Process. 12 1671-1683.

LUCE CH, TARBOTON DG and COOLEY KR (1999) Sub-grid parameterization of snow distribution for an energy and mass balance snow cover model. Hydrol. Process. 13 1921-1933.

MARKS D, DOMINGO J, SUSONG D, LINK T, GAREN D (1999) A spatially distributed energy balance snowmelt model for application in mountain basins. Hydrol. Process. 13 1935-1959.

MEYER PS (1999) An Explanation of the 1:500 000 General Hydrogeological Map. Oudtshoorn 3320. Department of Water Affairs and Forestry, Republic of South Africa.

MEYER PS (2001) An Explanation of the 1:500 000 General Hydrogeological Map. Cape Town 3317. Department of Water Affairs and Forestry, Republic of South Africa.

MIDGLEY DC, PITMAN WV and MIDDLETON BJ (1994) The Surface Water Resources of South Africa 1990. Volumes 1 to 6. Report Numbers 298/1.1/94 to 298/6.1/94 (text) and 298/1.2/94 to 298/6.2/94 (maps), Water Research Commission, Pretoria.
NAMIAS J (1985) Some empirical evidence for the influence of snow cover on temperature and precipitation. Mon. Weather. Rev. 113 1542-1553.

PARAJKA J, HOLKO L and KOSTKA Z (2004) Distributed modelling of snow water equivalent - Coupling a snow accumulation and melt model and GIS. Source from http://www.gisdevelopment.net/application/nrm/mountain/mount0007.htm.

RANGO A (1993) Snow hydrology processes and remote sensing. Hydrol. Process. 7 121-138.

ROSS D BROWN, BRUCE BRASNETT and DAVID ROBINSON (2003) Gridded North American Monthly Snow Depth and Snow Water Equivalent for GCM Evaluation. Atmos. Ocean 41 (1) 1-14.

STRACK JE, LISTON GE and PIELKE Sr RA (2004) Modeling snow depth for improved simulation of snow-vegetation-atmosphere interactions. J. Hydrometeor.- Spec. Sect. 5 723-734.

STRACK JE, PIELKE RA (Sr.) and ADEGOKE J (2003) Sensitivity of model-generated daytime surface heat fluxes over snow to landcover changes. J. Hydrometeor. 4 24-42.

TAYLOR CM, HARDING RJ, PIELKE RA (Sr.), VIDALE PL, WALKO RL and POMEROY JW.(1998) Snow breezes in the boreal forest. J. Geophys. Res. 103 (23) 087-23 101.

US ARMY CORPS OF ENGINEERS (1991) SSARR Model, Streamflow Synthesis and Reservoir Regulation. (Draft) as of August 1987, reprinted Jan 1991. 